Monika Reppo

\title{
SLOW AND DISCONNECTED? \\ THE HISTORIOGRAPHY OF 17TH-18TH \\ CENTURY GLASS IN ESTONIA AND THE \\ PROSPECTS OF INTERDISCIPLINARY \\ RESEARCH BASED ON \\ A CASE STUDY OF PÄRNU COUNTY
}

In 1628, a remarkable thing happened. Jost Wentzell started working as the first glass master in Hüti on the island of Hiiumaa in Estonia. Hüti has been synonymous with the early years of glass-making in Estonia as it is the first known site. All of the archaeological and archival data has been combined into a continuous narrative, but without archaeology we would only know that a glass furnace was supposed to have been built in Hiiumaa. Since no written records of Jost Wentzell's activities have survived, we only have the excavation results to characterise the glassworks at that time. However, the excavation would have never occurred without information from the written sources about Hüti ${ }^{1}$.

The interdependence of archaeological and archival research in the study of the Estonian glass industry is unmissable. Relying solely on 
archaeological records to describe the glass industry is not feasible as the excavations have been sporadic, the archaeological glass finds have only partially been studied, and the results are almost completely unpublished. And the same goes for the archival records. Unfortunately, no comprehensive chronology or historiography has been published on this topic. Thus, this article will provide muchneeded background for future studies on pre-industrial glassworks with an analysis of the historiography of 17 th-18th century glass in Estonia. Based on the state of current research, the analysis is divided into four topics - studies of a) the glass industry, b) the glass artefacts, c) the genealogy and d) the art history. As an extension of these topics, the second part of the paper provides a case study, examining the prospects of interdisciplinary research using the potential 17th century glassworks in Pärnu County as an example.

\section{THE STUDY OF THE ESTONIAN GLASS INDUSTRY - 18TH AND 19TH CENTURY AUTHORS}

Studying the history of glass in Estonia is characterised by a focus on the glassworks ${ }^{2}$ in Hüti, Rõika-Meleski and in the Kärevere (Kerrafer) region (Fig. 1). One of the earliest descriptions dates back to 1789. August Wilhelm Hupel, a Baltic-German encyclopaedist, provides a contemporary account of the Tõrna, Laeva and Kärevere glassworks, all in southeast Estonia ${ }^{3}$. His account is merely descriptive, but it offers valuable insights into demographics, work distribution and annual revenue. More forceful opinions are expressed in ethnologist Carl Russwurm's 1855 description of $\mathrm{Hüti}^{4}$, in which he praises Jacob de la Gardie for the foresight to start producing glass. Albeit short, the description is characteristic of 19th century accounts of glassworks in which the social history and impact of the sites become more important and is colourfully presented.

2 The term "glasshouses" is also used to denote pre-industrial glassworks, but to avoid confusion, the term "glassworks" will be applied throughout.

3 August Wilhelm Hupel, Die gegenwärtige Verfassung der Rigaschen und Revalschen Statthaltersschaft. Zur Ergänzung der Topographischen Nachrichten von Lief- und Ehstland (Riga: J. F. Hartknoch, 1789), 497-500.

4 Carl Russwurm, Eibofolke oder die Schweden an den Küsten Ehstlands and auf Runö. Erster Theil (Reval: J. J. Kelchen, 1855), 89.

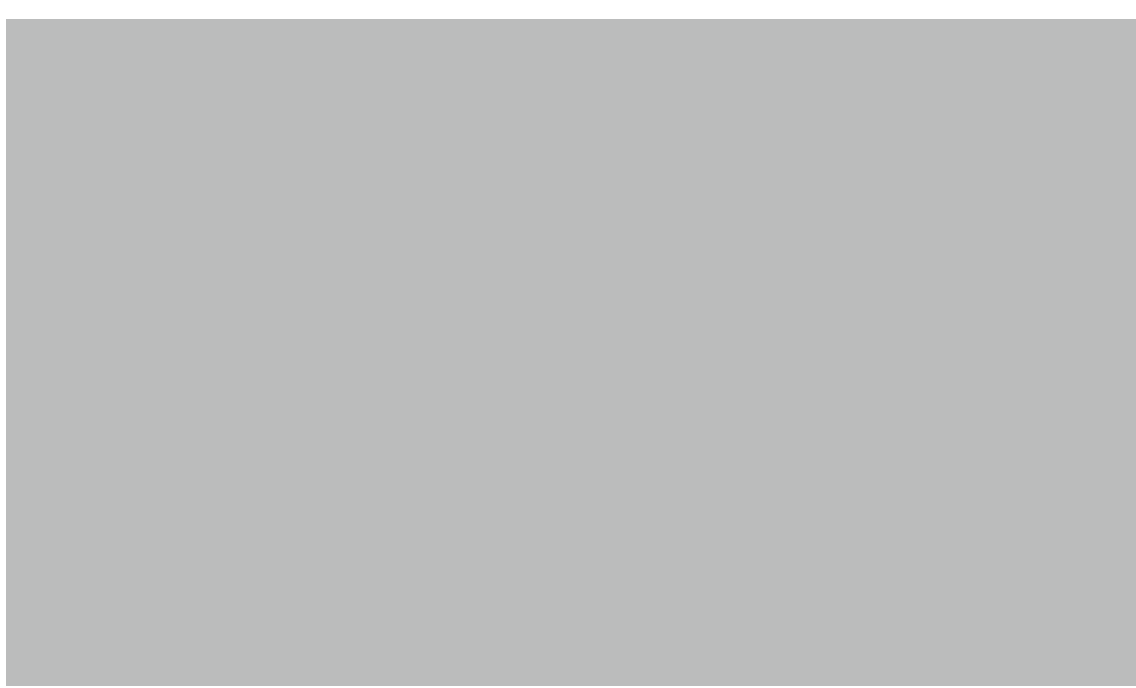

FIG. 1. ESTONIAN GLASSMAKING VILLAGES OR SETTLEMENTS (BLUE - 17TH CENTURY, RED - 18TH CENTURY) WITH CLEAR CLUSTERING IN CENTRAL ESTONIA. MAP BASED ON MODERN-DAY AREAS OF THE VILLAGES FROM HTTP://WWW.STAT.EE (ACCESSED 17 MAY 2019).

Along with Russwurm, there are two other notable 19th century authors who describe 18th century glass production. Friedrich Amelung, who inherited the Rõika-Meleski glass factory had a personal interest as well as access to sources related to the history of his factory ${ }^{5}$. Later, he combined the historical study with an analytical overview of the industrial boom and subsequent decline of different industries in Põltsamaa ${ }^{6}$. Amelung's research was complemented by a series of articles by pastor Villem Reiman ${ }^{7}$ that provide a vivid account of everyday life at the factory and, as a rare exception, include a description of the products. Although not scientific in the modern sense, these sources are valuable, as they form the basis of our knowledge about the history of glass production in Estonia. Works by

5 Friedrich Amelung, Die älteren Glashüttenanlagen des Major von Lauw seit 1764 und die Gründung der Spiegelfabrik Catharina-Lisette im Jahre 1792 (Dorpat: C. Mattiesen, 1876).

6 Friedrich Amelung, Studien zu Geschichte Oberpahlens und seiner industriellen Blüthezeit (Dorpat: C. Mattiesen, 1892).

7 Villem Reiman, 'Rõika-Meleski peeglivabrik 1792-1892', Postimees, 3.-5.08.1892, 3. 


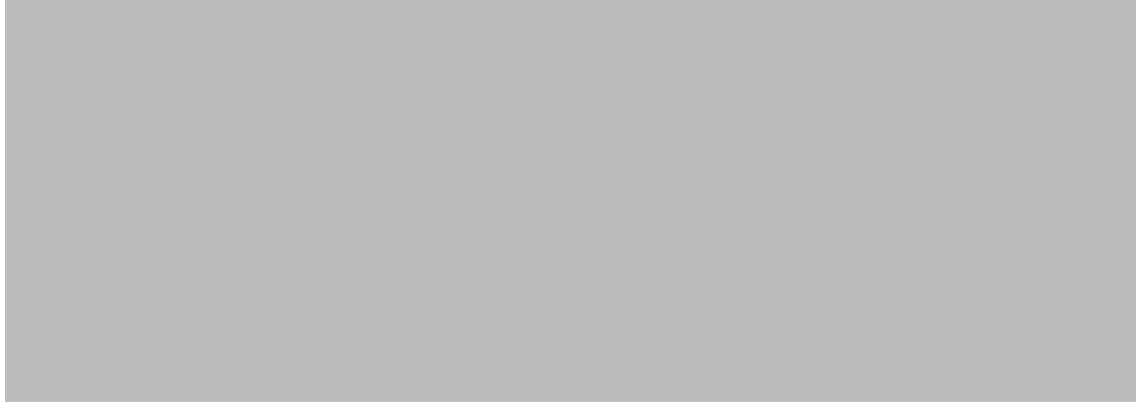

FIG. 2. STUDY OF THE GLASS INDUSTRY - A TIMELINE OF PUBLISHED RESEARCH.

Hupel, Russwurm, Amelung and Reiman also provide insights into the social composition as well as the cultural and financial impact of the glassworks. However, they offer little information on the actual products and only focus on three distinct regions. The accounts can also be biased, especially if the author had direct links to a factory. That being said, these studies have acted as a starting point for the majority of later studies.

\section{THE STUDY OF THE ESTONIAN GLASS INDUSTRY - SCIENTIFIC APPROACHES IN THE 20TH AND 21ST \\ CENTURIES}

The scientific study of the Estonian glass industry is characterised by short periods of active research followed by decades when no research seems to have been conducted (Fig. 2). Following this pattern, it took 46 years after Reiman's article for a renewed examination of the glass industry to be written. Published in 1928, historian Ina-Marie Friedenthal's dissertation on the development Estonian industries was the first attempt to study the subject scientifically ${ }^{8}$. Her research describes Hüti as the only industry outside of Tallinn during the
Swedish period (1561-1710). She considers the glass industry, along with the paper mills, to be the largest and most important during the Tsarist period. The Lehtse, Meeksi, Nurmsi, Laashoone, Tõrna and Rõika-Meleski glass factories (Fig. 1) as well as the mirror workshops are discussed. Most subsequent researchers have used this data but have neglected to acknowledge the importance of her pivotal study, or to recognise her as the first scientific researcher in the field.

Interest in Estonia's industrial past was renewed in the 1950s, although the focus was the 19th-20th century glass factories ${ }^{9}$. Historian Arnold Soom's study on 17th century manor estates was based on records that were unavailable to researchers in Soviet Estonia. It also includes data-rich references to Hüti, mentioned as the only glassworks in 17 th century Estonia ${ }^{10}$. The focus on the general industrial past is characteristic of the studies related to glass in the 1950s. A comprehensive chronology of known Estonian glassworks was presented in 1962 in two short articles by geographer Endel Varep ${ }^{11}$ that included information from historical documents, oral history, field walking and archaeological excavations in Hüti. The article is lacking in scope due to its length, but Varep's unpublished notes $^{12}$ indicate his research was much broader. These notes have been used as a starting point in the examination of the 17th century glassworks in Pärnu County, which is presented in the second half of this article. Historian Otto Karma's $1963^{13}$ study has been considered the most comprehensive $\mathrm{e}^{14}$, and this is true of the coverage of the later periods, but the data from the 17th and early 18th centuries repeats the information found in Varep's publications with only minor differences. Karma is extremely meticulous and his study is

9 Leida Loone, 'Iz istorii promyshlennogo perevorota v Estonii', Voprosy istorii, 5 (1952), 77-96; Raul Renter, Suurtööstuse tekkimine ja arenemine Eestis XIX ja XX sajandil (Tallinn: Eesti Riiklik Kirjastus, 1958).

10 Arnold Soom, Der Herrenhof in Estland im 17. Jahrhundert (Lund: Skånska Centraltryckeriet, 1954), $176-178$.

11 Endel Varep, 'Klaasitööstusest Eestis. Peatükk Eesti loodusvarade kasutamise ajaloost', Eest Loodus, 3 (1962), 137-141. Endel Varep 'Klaasitööstusest Eestis. Peatükk Eesti loodusvarade kasutamise ajaloost', Eesti Loodus, 4 (1962), 199-204.

12 Endel Varep's settlement history file archive at the Insitute of Estonian Language. His collection contains more than 94,000 catalogue cards including research notes on glassworks. 13 Otto Karma, Tööstuslikult revolutsioonilt sotsialistlikule revolutsioonile Eestis (Tallinn: ENSV TA, 1963).

14 Andres Tvauri, 'Archaeological investigations on the sites of the glassworks of Central Estonia', Archaeological Fieldwork in Estonia 2012 (Tallinn: Muinsuskaitseamet, 2013), 259-270. 
significant as it presents documentary evidence on the economic and social structure of the glassworks, but also includes the industries that used the glass, such as distilleries. The acceptance of material culture and fieldwork as viable sources sets the studies of the 1960s apart from previous periods. Overall, the 1950s and 1960s can be considered to be the period when the most active study of the industry and technology has taken place to date.

The most thorough research was undertaken by glass artist Maks Roosma. His monograph chronicles the history of the glassworks at Hüti (1628-1664) $)^{15}$. Roosma's studies were innovative for Europe at a time when industrial archaeology was in its infancy. The seminal book is well-illustrated and includes photocopies of archival records, and unlike previous researchers, Roosma covers the construction of the furnaces and the production. However, it appears that very few finds, other than glass waste, were found. This may result from Roosma lacking a background in archaeology. A more thorough study of the material culture would have enabled a better analysis of the everyday life at the site, although the socioeconomic and socio-political backgrounds are discussed in detail. The impact of the political situation forms the core of Roosma's 1969 article based on his excavations in Piirsalu, Rekka, Gorodyonka and Laashoone ${ }^{16}$ (Fig. 1). Unfortunately, Roosma died soon after and several of his manuscripts remain unpublished, including an overview of Estonian glass factories ${ }^{17}$ between the 17 th and 20 th centuries. By the $1960 \mathrm{~s}$, a good overview of the history of the Estonian glass industry had been obtained by combining Roosma's, Varep's and Karma's works.

Nearly half a century had to pass before another archaeological look at glass production in Estonia took place. In 2010-2012, archaeologist Andres Tvauri conducted scientific surveys and excavations at Utsali $^{18}$, Laashoone, Laasme, Altnurga, Tõrna, Hoone and Haava ${ }^{19}$

15 Roosma, Hüti klaasikoda. Jooni klaasimanufaktuuri tegevusest Eestis XVII sajandil.

16 Maks Roosma, 'The glass industry of Estonia on the 18th and 19th century', Journal of Glass Studies, 11 (1969), 70-85.

17 Maks Roosma, Eesti klaasitööstuse arengujooni XVII sajandist XX sajandi neljakümnendate aastateni. (Manuscript, Estonian Art Academy, 1971).

18 Andres Tvauri, 'Archaeological investigations of the 18th century glassworks at Utsali', Archaeological Fieldwork in Estonia 2011 (Tallinn: Muinsuskaitseamet, 2012), 113-124.

19 Tvauri, 'Archaeological investigations on the sites of the glassworks of Central Estonia', $259-270$.
(Fig. 1). These are the most recent excavations to date. As before, the furnace structure and technology were the main focus, but some attempt was successfully made in identifying the products. And of the more recent works, Tvauri's is certainly the most extensive. In other recent studies, designer Helen Laos has described the history and characterised the production of Rõika-Meleski. However, she notes that she is unqualified to classify and date the production ${ }^{20}$. This perfunctory approach leaves the reader with an incomplete overview. In 2015, Teele Jürivete focused on 19th-20th century glassworks, ${ }^{21}$ but she also provides a page-long overview of earlier sites. Unfortunately, her survey suffers from relying heavily on interviews and this leaves the reader speculating as to what's fact and what's hearsay. Overall the historiography of the glass industry in Estonia, with its focus on the same regions, concentrates on Hüti, Rõika-Meleski and the Kärevere area. The studies are relatively sporadic in nature and characterised by decades-long gaps.

\section{ARTEFACT STUDIES}

The study of artefacts has been even more sporadic in nature. Ain Mäesalu's 1986 article $^{22}$ on mediaeval beakers marks the beginning of the typological study of glass vessels found in Estonia, which for many decades had lagged behind Western and Northern Europe. However, except for Roosma's study, early modern and modern archaeological glass remained unresearched until very recently. The marginal role of glass is linked to the historical development of the discipline in Estonia and Europe ${ }^{23}$ where most urban sites rely on rescue excavations that are carried out by private companies. A lack of time, finances and specialists can lead to the incomplete

20 Helen Laos, Peegli- ja klaasitööstus Eestis (unpublished BA thesis, Mainor Busines School, 2011): https://is.eek.ee/download.php?t=kv\&dok=DOK4da98bfclfee4.pdf (accessed 15 May 2019), 24

21 Teele Jürivete, Eesti klaasitööstus 19. sajandist 20. sajandi alguseni suuremate klaasivabrikute näitel (unpublished BA thesis, University of Tartu, 2015): http://dspace.ut.ee bitstream/handle/10062/48561/Teele_Jyrivete_BA_2015.pdf (accessed 15 May 2019).

22 Ain Mäesalu, 'Unikale Glasfunde aus Tartu', ENSV TA Toimetised. Ühiskonnateadused, 39 (4) (1986), 400-402.

23 Erki Russow, 'Post-Medieval archaeology in Estonia', Archaeological Research in Estonia 1865-2005. Estonian Archaeology I, ed. by Valter Lang, Margot Laneman (Tartu: Tartu Ülikool Kirjastus, 2006), 193-203. 
processing of finds. As a result, glass is usually omitted or mentioned only passing in the reports. Thus, my statistics for glass finds from Tartu Rd 1 in Tallinn are more of a descriptive dataset than a proper analytical overview ${ }^{24}$ and are an example of the struggles inherent to many commercial archaeology projects. My more recent research ${ }^{25}$ has focused on the historiography of glass research in Estonia and the consumption of glass vessels in Tallinn from the 13th to the 20th century, based on a fairly large dataset of 6,000 glass items. A short overview of the vessels was published in $2017^{26}$. Historiographically speaking, medieval glass finds have received more attention in archaeology. The same applies for 19th and 20th century glass in art history, whereas the study of early modern glass has largely lagged behind in both disciplines. Therefore, in addition to providing an overview of the early years of the Estonian glass industry, this article also tries to bridge the gap between the studies on medieval and industrial glass.

My current focus has been on the role of migration in the production and consumption of glass in 17th and 18th century Estonia. My analysis of the glass vessels and flat glass, as they related to an 18th and 19th century greenhouse, included in a study on the use-history of a post-medieval urban site is one of the only examples of its kind in Estonian archaeolog $y^{27}$. Based on my research, flat glass comprises almost half of the archaeological glass stored in Tallinn, so it is surprising that so little has been done with these finds. A few published art history studies on 17th or 18th century flat glass can be found. For example, Eve Koha examined the 17th and 19th century restored stained glass windows exhibited at the Holy Spirit Church in Tallinn ${ }^{28}$. Archaeologically speaking, no studies on stained glass

24 Erki Russow, Lembi Lõugas, Liina Maldre, Sirje Hiie, Kersti Kihno, Heidi Luik, Villu Kadakas, Krista Sarv, Ulla Kadakas, Anneli Kalm, Monika Reppo, 'Medieval and early moder (E)

25 Monika Reppo, Consuming glass vessels in medieval and post-medieval Hanseatic towns: the case of Tallinn (Reval), Estonia (unpublished MA thesis, Tallinn University, 2016).

26 Monika Reppo, 'Muutused tallinlaste tarbimisharjumustes: klaasanumad keskajast hilisuusajani', Tutulus 2016 (2017), 16-17.

27 Liivi Varul, Silvia-Kristiin Kask, Mauri Kiudsoo, Liina Maldre, Kalmerg Mäeorg, Monika Reppo, Erki Russow, Aivar Kriiska, 'Archaeological investigations on Tonnismagi lla and Pärnu Road 44 plots in Tallinn', Archaeological Fieldwork in Estonia 2017 (Tallinn: Muinsuskaitseamet, 2018), 175-192.

28 Eve Koha, 'Tallinna Püha Vaimu kiriku haruldased klaasimaalid', Muinsuskaitse astaraamat 2009 (Tallin : have been published. 17th-18th century glass beads are another area that remains unstudied. PhD student Irita Kallis has been compiling a study on Estonian archaeological beads since 200929, but she has not published anything on the post-medieval period. Besides my MA study and a handful of articles, studies on 17th and 18th century glass artefacts and objects seem to be a very niche topic.

\section{GENEALOGIES}

Another niche topic that has been relatively well studied seems to be the genealogy of the early Estonian glassmakers. A study of German glassmaking families by Robert Feldmann (1875-1927), the heir to the Laeva glass factory, was believed to have been lost until recently. His son Robert Feldman Jr. published a summary of his father's work in $1935^{30}$. It includes a list of 175 German glassmaking families from 1628 to 1860 and provides an insight into the influences that have impacted the techniques and styles. Feldman's original work was rediscovered in 2008 and Dirk-Gerd Erpenbeck was the first to look into the data. In 2015, he published his study on 18th century glassmakers and glassworks operating in the Baltics ${ }^{31}$. Due to its scope, it is a particularly useful starting point for any future studies related to the social structure of most 18th century glassworks in the region. Earlier migration and cultural differences are also described in Ville Dreving's overview of Rõika-Meleski ${ }^{32}$ although it is not a scientific study, but rather an attempt to gather all the known material without any proper, unbiased analysis. Due to the fragmented nature of the archaeological and archival records and research of glass production in Estonia, genealogical and archival information is still extremely valuable.

Another type of "genealogy" becomes apparent when looking at the probate inventories that can also be seen as object genealogies.

29 Irita Kallis, Klaasist ja mineraalidest helmed Eesti arheoloogilises materjalis: https:// www.etis.ee/Portal/Mentorships/Display/fd63f89c-dea2-4aad-b291-c024b7747e16 (accessed 15 May 2019).

30 Robert Feldmann, 'Verzeichnis sämtlicher Glasmacher-Familien in Est- u. Livland', Baltische Familiengeschichtliche Mitteilungen, 3 (1935), 40-42.

31 Dirk-Gerd Erpenbeck, 'Glasmacher und Glashütten im Baltikum im 18. Jahrhundert', Die baltischen Länder und Europa in der Frühen Neuzeit, ed. by Norbert Angermann, Karsten Brüggemann and Inna Põltsam-Jürjo (Köln: Böhlau, 2015), 301-328.

32 Ville Dreving, Meleski klaasivabriku kolm sajandit (Tartu: Eesti Ajalookirjastus, 2013). 
Historian Lauri Suurmaa has used these to assess the use of table and kitchenware in 18th century Tallinn and describe changes in the material culture ${ }^{33}$. As the study includes an inventory of the glass merchant V. Horn (+1737) and information on the types of glass vessels owned by a variety of households, it is a good source related to 18th century glass. Although inventories are often incomplete, socially biased, do not record net accumulation, vary in detail and mostly represent men at the end of their life-cycles ${ }^{34}$, I consider them to be valuable sources for determining the acquisition and consumption patterns of moveable possessions, something that is often impossible for earlier periods. For an interdisciplinary study on the consumption of glassware, these combined records are invaluable as they list the vessels that were used, but also link them to certain types of households and individuals. Together with the genealogy of the glassmakers, these records provide a more complete understanding of glass in 17th and 18th century Estonia.

\section{ART HISTORY}

A totally different issue arises when art as a source, as well as art history methods, are used to study Estonian glass and the industry in the 17th and 18th centuries. Although examples from European art have been used relatively widely, the emphasis has only been on providing illustrative examples of glass vessels that tend to be preserved as fragments in the archaeological record. This has allowed comparisons to be drawn with contemporary material from elsewhere in Europe and for speculations on the potential use of glass drinking vessels to be suggested ${ }^{35}$, but it has not been employed in identifying or dating vessels. Pictorial sources have not been used to study any other form of glass from the period under consideration.

While European art has been used to some extent in the studies of the period, it is notable that examples of local art have only been

33 Lauri Suurmaa, 'Tallinna saksa kaupmeeste varaloendites inventeeritud laua- ja kööginõud kultuuriajaloo allikana 18. sajandil', Vana Tallinn XV $(X I X)$, ed. by R. Pullat (Tallinn: Estopol, 2004), 9-154

34 Paul Glennie, 'Consumption within historical studies', Acknowledging consumption. A review of new studies, ed. by D. Miller (London: Routledge, 1995), 163-201.

35 Reppo, Consuming glass vessels in medieval and postmedieval Hanseatic towns: the case of Tallinn (Reval), Estonia, 50, 94. used once. In his seminal study, Maks Roosma drew stylistic and technological comparisons between the material from Hüti and the visual representations of glass production and use in European art and literature. However, he was also able to find material from Hiiumaa folk costumes and Estonian folk art that could be compared to the decorative style used in the engraved vessels at Hüti ${ }^{36}$. Thus, Estonian archaeology is no different than most European archaeology, and art history has not been used to its full potential as a resource. There is a clear need to identify prospective genres, themes and mediums that are relevant in Estonia. And what other local forms of contemporary iconographic sources could be used?

Although we cannot rely on a collection that is as impressive as that of the Dutch Golden Age, a variety of sources can still be employed. In terms of the glass industry, an interesting set of reference material is available. In at least three cases from Hüti, the glass masters and apprentices used stylised glass vessels in their signatures or seals - Jürgen Wentzell used a trailed beaker, Hans Gudt, a square glass bottle or flask, and Pauell Gauwkunkell, a römer. ${ }^{37}$ All were very common in the mid-17th century and also produced locally. As explained below, there are also some preserved schematic images of glass factories on contemporary maps (Fig. 5) that have not been studied from an art history point of view.

Unfortunately, the depictions of glass vessels in the 17th and 18th century religious and secular paintings commissioned or painted in Estonia comprise a completely unstudied subject, so it is unclear how many examples exist in local art collections. For example, glass vessels as a motif in still lifes and genre paintings continued well into the 19th century. In Estonia, Julie Hagen-Schwarz's (1824-1902) rich floral bouquets in glass vases and Oskar Hoffmann's (1851-1912) tavern scenes with bottles and tumblers are good examples of the depictions of glass vessels readily available in the archaeological record, albeit unstudied from this point of view. Another research avenue could be the depictions of glazed windows on engravings and paintings as window glass is already an understudied topic in Estonian archaeology. As mentioned above, stained glass windows have

36 Roosma, Hüti klaasikoda. Jooni klaasimanufaktuuri tegevusest Eestis XVII sajandil, ill. $113-116$.

37 Ibidem, ill. 109, 120, 34. 
received some attention from art historians, but have not generally been described from an artistic point of view by archaeologists.

Using art history methods and sources when studying postmedieval material culture can provide locations for archaeological objects, in relation to spaces, other objects and people that are generally missing in the end of "life" contexts where the artefacts are found (e.g. dumpsites, cesspits, debris layers). Although considered to be partial, occasionally biased, and certainly not mimetic ${ }^{38}$, being informed by social, moral and cultural motivations is just a singularity and should not be seen as an obstacle when using pictorial sources. Comparative research, which employs both archaeological and art history sources and methods, makes use of this and avoids the research material being 'orphaned and only of interest to other archaeologists ${ }^{\prime 39}$. But as has been shown above, although the importance of pictorial sources has been recognised in Estonian archaeology, its full potential has not been realised.

\section{INTERDISCIPLINARY? THE RESEARCH PROSPECTS OF} 17TH CENTURY GLASSWORKS NEAR PÄRNU

The importance of an interdisciplinary approach in the study of glass in Estonia is further supported when we consider what archaeology can tell us when combined with historical research. Although Hüti is considered to be the earliest glassworks in Estonia, archival records indicate that it may have been preceded by glassworks near Pärnu. This possibility has largely been left unexplored and unpublished Using genealogy, cartography, typology and archival research, the following section of this paper demonstrates how inter- and intradisciplinary approaches can provide vital clues regarding the location of the site and the date, thereby paving the way for archaeological fieldwork.

The starting point can be found in two letters from 1662. These indicate that Magnus de la Gardie wished to move the workers from Hüti to Count von Thurn's glassworks in Pärnu County. He had acquired the area in 1661 and wanted to satisfy the need for window

38 David Gaimster, 'Artefacts, Art and Artifice: Reconsidering Iconographic Sources for Archaeological Objects in Early Modern Europe', Post-Medieval Archaeology, 46/2 (2012), 304-319.

39 Ibidem, 317

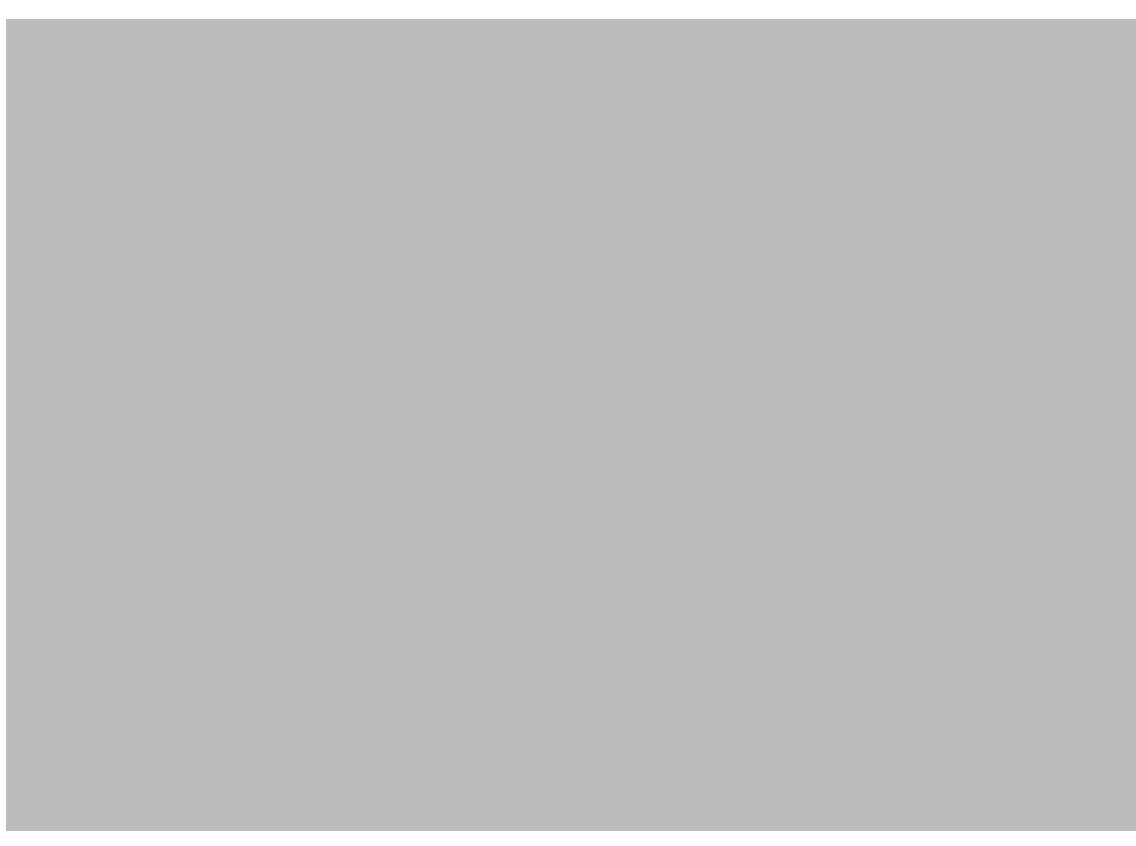

FIG. 3. A SIMPLIFIED FAMILY TREE OF THE VON THURN-VALSASSINA FAMILY.

glass in the near future and to employ von Thurn's workers ${ }^{40}$. This is the first indication that at least one other glassworks operated in Estonia at the same time with Hüti. However, in the spring of 1655 , glass master Wilhellm Breidenstein claimed that Hüti was the only glass factory in Estonia ${ }^{41}$. Based on this statement, Roosma speculated that the death of Count Heinrich Matthias von Thurn around 1654 lead to the closure of the glassworks near Pärnu ${ }^{42}$. This sounded very likely

40 Roosma, Hüti klaasikoda. Joonis klaasimanufaktuuri tegevusest Eestis XVII sajandil, ill. 50, 52. Held at the Stockholm State Archive [Riksarkivet Stockholm, SE.RA], De la Gardiesk samlingen, Magnus Gabriel De la Gardies samling, 720222-01, 18.02.1662 and 13.04.1662.

41 Ibidem, ill. 51. Previously held at the State Archive Göttingen [Staatliches Archivlager Prussian Cultural Heritage Foundation [Geheime Staatsarchiv Preußischer Kulturbesitz, GStA $\mathrm{PK}]$.

42 Ibidem, 43 
until we revisit the genealogical sources that indicate he had already died in 1640. The von Thurn that was referenced in the letters could be Heinrich von Thurn-Valsassina, his grandson and heir, who died in Riga in 1656. Further complications arise since he did not become the Count of Pärnu until 1654, whereas Endel Varep's unpublished research indicates there was a glass working site near Pärnu by $1646^{43}$ at the latest. Who was the owner? And when was it founded?

The von Thurn family (Fig. 3) arrived in Estonia from the modernday Czech Republic due to Heinrich Matthias von Thurn's (1567-1640) exile in 1620, which resulted from his role as a leader of the Protestant Bohemian Revolt against Emperor Ferdinand II. He settled in Pärnu. By 1625, his son Franz Bernhard von Thurn-Valsassina (1592-1628) already owned the area that would be formed into Graftschaft Pernau or Pärnu County in 1627. He died the following year and the county went to his widow Magdalena Prüschenk von Thurn, née von Hardegg (Hardeck; +1651 Pärnu). Magadalena rented out the manors, thereby increasing the possibility that, from 1628-1651, someone outside the von Thurn family could have started producing glass. However, this is unlikely as the place is only referred to as "von Thurn's". Further clarity could be achieved by working through the archival materials related to Heinrich von Thurn-Valsassina, as the glassworks would have been part of his inheritance since his brother had died a few decades earlier.

The archival material is from the mid-1650s. Therefore, in terms of the potential glassworks, it is probably too late considering what we know from other sources. But obviously, the abandoned glassworks could have been mentioned in these records in passing - extensive archival work is needed to rule out this possibility. For example, the material includes letters sent to Heinrich between 1653 and $1655^{44}$, with several from Wilhellm Breidenstein. He was the glass master at Hüti and the letters could yield information about when it opened, closed and where it was situated. But what if Heinrich, the heir, was not the founder of the factory? It is of note that Magdalena Prüschenk von Thurn was no ordinary woman. While she ruled the estates of Pärnu County in the 1620s, the tensions between Pärnu

43 Endel Varep's settlement history file archive at the Insitute of Estonian Language, Audru 44 National Archives of Estonia [Rahvusarhiiv], EAA.1.2.174. Kirjad kuberner krahv Heinrich von Thurnile.

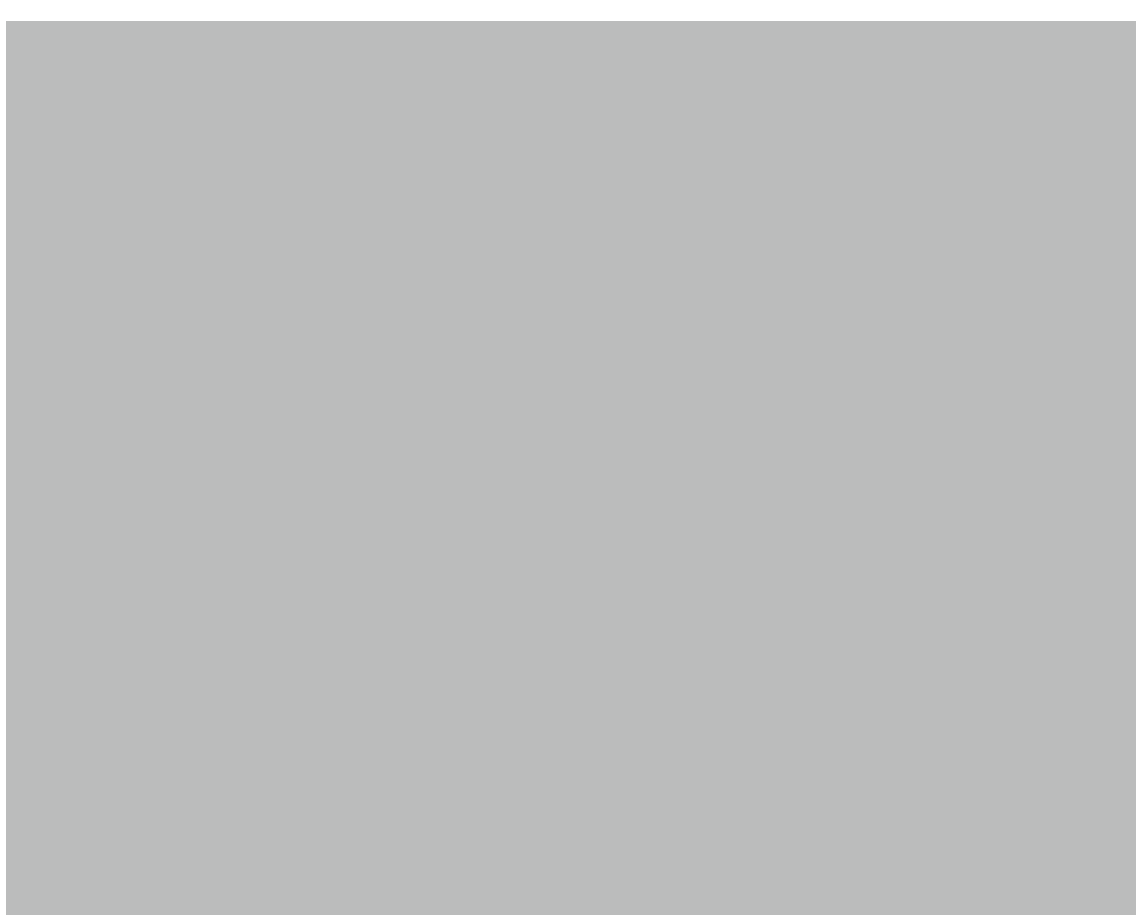

FIG. 4. SMALL MEDICINE JARS. PÄMU 14350/A 2501:18. PHOTO: MONIKA REPPO, 2019.

and the noble family intensified. For example, she rebelled against the court reform and held her own court ${ }^{45}$. She also built dams on the river obstructing traffic ${ }^{46}$. Being an entrepreneurial woman, she may have been aware of the potential material (supply) and financial gains (revenue, savings) of owning glassworks of her own.

The finds in the Pärnu Museum also indicate that in the 17th century, glass was very available in Pärnu, and numerous examples of different glass vessels are included in the museum's collection. The greatest number of these are small medicine jars (Fig. 4) made of bluish-green forest glass and larger bottles of similar glass. The

45 Heikki Pihlajamäki, ““... nii et ühelgi osalisel poleks põhjust kaebamiseks”. Rootsi 1630. ja 1632. aasta alamkohtute reform ja talurahvakohtud Liivimaal', Akadeemia, 4 (337) (2017), 586-610.

46 Enn Küng, 'The plans for making the Pärnu-Viljandi-Tartu waterway navigable in 16301680', Ajalooline Ajakiri, 3/4 (129/130) (2009), 432. 


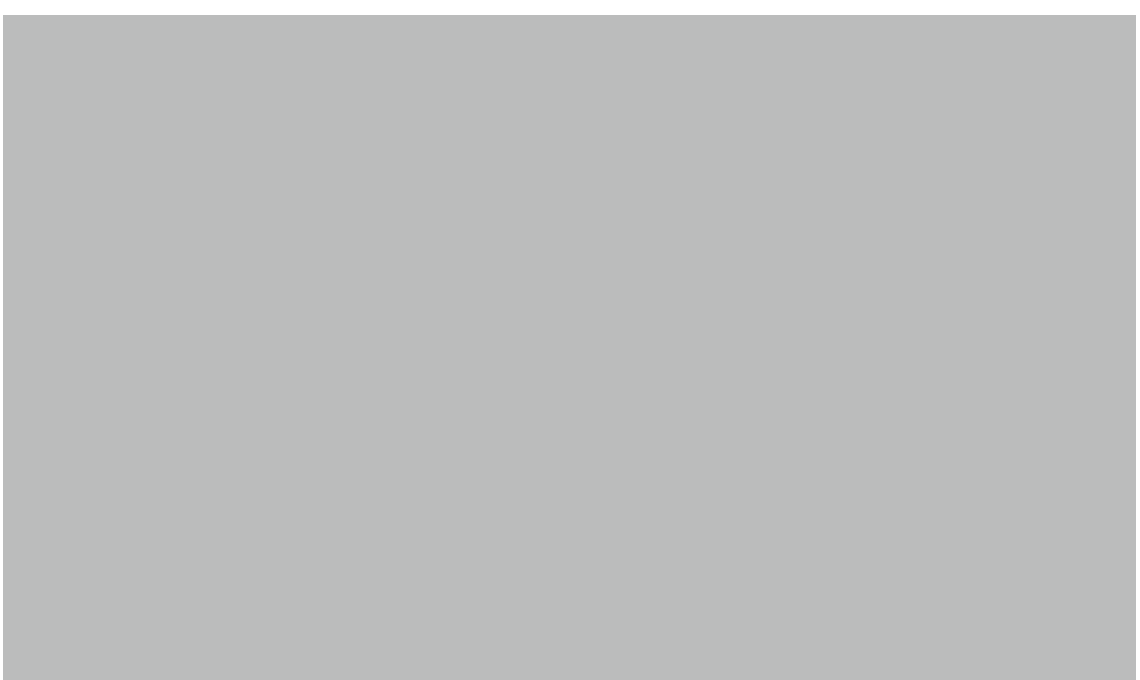

FIG. 5. LOCATION OF THE GLASSHOUSE ON THE 1704 MAP WITH PLACE NAMES. BLUE FOR BODIES OF WATER, GREEN FOR THOSE IDENTIFIED WITH CERTAINTY, AND ORANGE FOR POTENTIAL MATCHES. NATIONAL ARCHIVES OF ESTONIA, FRAGMENT FROM EAA.308.2.28

jars are especially significant because fewer than five examples are known to exist from elsewhere in Estonia. The forest glass found in Pärnu is exceptional for the blue-green colour and differs from the moss-green colour of most Hüti vessels. However, in some batches at Hüti, the presence of copper or other impurities give the glass a slightly blueish tint. The forest glass at Pärnu also differs stylistically - the vessel walls are very thick, whereas the masters at Hüti seem to have been able to produce vessels with much thinner walls. In any case, before the 17th century, glass bottles, jars and apothecary ware were virtually non-existent in the archaeological material of Pärnu.

But where was the glassworks located? Roosma does not speculate on potential locations, neither does Varep. Varep did consider several in his notes, namely Audru, Võlla, the area of Potsepa in the village of Kõima, and Rääsa farm in Soeva village. Based on the location of a glasshouse on a map from $1704^{47}$ (Fig. 5), it could have been located upstream from Audru, so the area of Jõõpre and Ridalepa are possibilities. It is likely that the right branch of the river indicated near the glassworks is the modern day Audru River, whereas the left branch could be the Oara stream. Some reassurance can be found in the inscription above these two rivers 'Här gar ingen Wäg igenom' - 'No roads go through here', indicating the location of the Laasma mire. Interestingly, of the options considered by Varep, Soeva village is not far away, but it is on the west side of the river. However, the map is inaccurate in other ways. Other maps from this period available to researchers in the register of maps ${ }^{48}$ do not show any glassworks in the area.

A map from the early 18th century shows the Hüti glassworks in ruins, but the glassworks near Pärnu seems to be operational. So, were there two separate factories or is this the reopened von Thurn factory? Based on genealogical information published by Feldmann and Roosma and gathered by Varep, we might be able to determine which of the glassworkers lived near Pärnu during this period because the next factory that was established did not open until 1740 in Piirsalu, Lääne County. Unfortunately, the period covered by Erpenbeck's study is too late, whereas Inna Põltsam-Jürjo does not believe that the early 16th century glassmakers (glazemaker) were employed in glassmaking but rather in glazing or glass painting. However, potash production and a sand hill (santhbarch) are mentioned ${ }^{49}$.

The glassworkers from the 1628-1711 period that appear in the previous studies by Feldmann, Roosma and Varep were examined The year 1711 has been chosen as the final date because of the temporal proximity to the map compiled in 1704, and the fact that no glassworkers in Feldmann's list were known to have been alive in the decade after 1711. Of course, this data can be skewed, as it relies on surviving records which, similarly to archaeology, can result in missing or inaccurate information. Some of the data currently lacks any information where the workers were located. The databases in the National Archives of Estonia are open access so identifying the origins or places of residence for at least some of the workers should be possible. Unfortunately, earlier records are not referenced or

48 Register of maps in the National Archives of Estonia: http://www.ra.ee/kaardid/index php/en (accessed 17 May 2019).

49 Inna Põltsam-Jürjo, Liivimaa väikelinn Uus-Pärnu 16. sajandi esimesel poolel (Tallinn Argo, 2009), 295-296. 


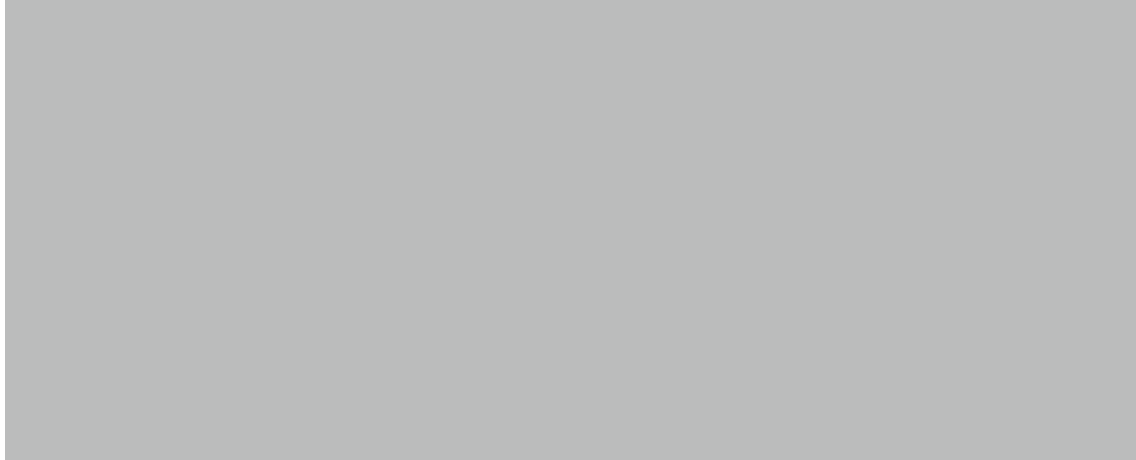

FIG. 6. TIMELINE FOR PÄRNU GLASSWORKS ALONGSIDE THE APPEARANCE OF GLASSWORKER IN WRITTEN RECORDS,

properly listed, which complicates the study to some extent. Still, it is obvious that there was a continuous influx of glassworkers starting in the 1640s, with clear peaks in 1680, 1700 and 1710, that is, if we disregard the glaziers from 1661 who were not glassmakers per se. Thirty-five surnames are listed for this period but, for example in the Wentzell family, several members were employed as glassmakers or apprentices in Hüti. However, those who worked at Hüti cannot be completely ruled out from working at Pärnu. For example, the apprentice Jürgen Wentzell probably moved to Pärnu after Hüti closed down since his wife Elsz (neé Bredensteen) died there in the $1690 \mathrm{~s}^{50}$. Thus, the lists represent the minimum number of families employed in glassmaking from 1628 until 1711, and despite potential errors, it is possible to identify the time periods when the glassworkers settled in Estonia.

What does all of the above tell us about the site in Pärnu? Looking at the timeline (Fig. 6), we see that archival records indicate that in the 1660s, there is a plan to restart the glassworks that seem to have closed before 1655, but were in operation in 1646. It opened its doors while either Count Franz von Thurn-Valsassina, or his widow Magdalena Prüschenk von Thurn, owned the area. And the

50 Roosma, Hüti klaasikoda. Jooni klaasimanufaktuuri tegevusest Eestis XVII sajandil, 97. latter's death was perhaps the reason it closed. During this period, the appearance of a large numbers of simple, lower quality forest glass items appears in the archaeological record of Pärnu. Thanks to cartography we can assume that the factory was somewhere around Jõopre and Ridalepa and was in operation when the map was drawn in 1704. The continued influx of glassworkers into Estonia after the closure of Hüti in 1664 allows one to speculate that Magnus de la Gardie or his successors carried out his plan and reopened the glassworks. Of course, the possibility remains that the "glass hut" we see on the 1704 map is a third separate factory that existed in addition to Hüti and von Thurn's factory.

\section{CONCLUSION}

The significance of the historiographical background of a subject hardly needs justification, but the historiographical research for 17th and 18th century glass in Estonia has been anticipated since the prior research had only been introduced in passing and often omitted lesser known works and authors. Four categories - a) industrial archaeology, b) artefact studies, c) genealogy and d) art history have been examined. The study of glass production and the producers, i.e. the glass masters and apprentices, has predominated, whereas the products, consumers and traders are usually overlooked. Art history has generally been ignored albeit works by European painters have been used by archaeologists to provide illustrative material for local fragmentary finds. The prospects for interdisciplinary research are shown based on the Pärnu glassworks by using previously unstudied and unpublished data. Based on genealogy, typology, stylistics, cartography and archival sources, it is certain that a factory did exist near Pärnu. The information presented here will be used as a basis for fieldwork in the region and hopefully to carry out excavations on the site. Combining archaeology with the material available from past historical and genealogical studies and unstudied written and iconographic records has already proven to be instrumental at Hüti, in order for a comprehensive examination of early glass production and consumption in Estonia to be conducted. It is hoped that this will also be possible for Pärnu, and that it will potentially result in the history of the first years of glass production in Estonia being rewritten. 
Monika Repro: Slow and Disconnected? The historiography OF 17th-18Th CENTURY GLASS in Estonia and the prospects of INTERDISCIPLINARY RESEARCH BASED ON A CASE STUdY OF PäRNU COUnTy

KeyWords: GLASS; Historiography; 17th CENTURY; 18Th CENTURY; PÄRNU; HÜTI

\section{SUMMARY}

This article provides an overview of the research into 17th-18th century glass in Estonia that has been lacking to date. Works on industrial archaeology, artefact studies and genealogy are discussed, thereby offering a useful reference point for comparative studies on regional dynamics, influences on glass consumption and production, and the origins of foreign products, merchants and glassmakers. The use of art as an iconographic source is described in an attempt to present material that could help to realise art history's full potential in studying glass in Estonia during this period. The potential of interdisciplinary research that combines all of the sources noted above is highlighted through a case study on the research prospects of Pärnu glassworks based on previously unstudied and unpublished data. Based on information from archival records, genealogy, cartography and typology, it is determined that a factory did exist in Pärnu in the first half of the 17th century that could potentially be even older than the factory at Hüti. This could significantly change our understanding of the beginning of glass production in Estonia.

\section{CV}

Monika Reppo, MA (b. 1989) is a PhD student at the University of Tartu's Institute of History and Archaeology, as well as the leading specialist in archaeology at Agu EMS Ltd. She has studied and worked in Tallinn and Sheffield, most recently as the leading archaeologist at the excavation of Paks Margareeta (Fat Margaret's cannon tower) and supervisor at the Scremby Osteological Field School in Lincolnshire. Her main research interests are urban material culture and the production and consumption of post-medieval glass. 